\title{
Comparative haemodynamic dose response effects of propranolol and labetalol in coronary heart disease
}

\author{
B SILKE, G I C NELSON, R C AHUJA, S H TAYLOR \\ From the University Department of Cardiovascular Studies and Department of Medical Cardiology, The General \\ Infirmary, Leeds
}

SUMMARY The immediate haemodynamic dose response effects of beta blockade (propranolol: 2 to 16 $\mathrm{mg}$ ) were compared with those of combined alpha beta blockade (labetalol: 10 to $80 \mathrm{mg}$ ) in a randomised study of 20 patients with stable angina pectoris. After control measurements, the circulatory changes induced by four logarithmically cumulative intravenous boluses of each drug in equivalent beta blocking doses were evaluated at rest, after which comparison of the effects of the maximum cumulative dose of each was undertaken during a four minute period of supine bicycle exercise.

Propranolol, at rest, induced significant dose related reductions in heart rate and cardiac output, with reciprocal increases in the systemic vascular resistance and pulmonary artery occluded pressure; systemic arterial pressure was unchanged. Labetalol was followed by significant dose related decreases in systemic blood pressure and vascular resistance associated with a significant increase in cardiac output; heart rate and pulmonary artery occluded pressure were unchanged. The slope of the left ventricular pumping function curve relating output to filling pressure from rest to exercise was significantly depressed by propranolol but unchanged after labetalol.

The less deleterious effects on left ventricular haemodynamic performance after alpha beta blockade in contrast to beta blockade alone in ischaemic heart disease may be attributable to the concomitant reduction in left ventricular afterload associated with the alpha blocking activity of labetalol.

A major consequence of coronary heart disease is a reduction in left ventricular haemodynamic performance; the increased workload of exercise frequently results in its acute but reversible pumping failure. ${ }^{1-3}$ The symptomatic effectiveness of beta blocking drugs is a result of the reduction in heart rate and myocardial contractility, two of the major determinants of left ventricular oxygen consumption. ${ }^{4} 5$ These haemodynamic advantages, however, may be offset to a varying extent by the accompanying increase in enddiastolic pressure ${ }^{67}$ and volume ${ }^{89}$ which result from blockade of the inotropic beta adrenoceptors in the left ventricle. Increase in end-diastolic pressure can be expected to increase subendocardial coronary resistance, and the increase in end-diastolic volume to offset some of the saving in left ventricular oxygen consumption achieved by the reduction in heart rate and myocardial contractility.

Accepted for publication 22 June 1982
A further disadvantage of beta blocking drugs in coronary heart disease is their propensity to increase the peripheral vascular resistance; this stems from two sources. First, the decrease in systemic arterial pressure $^{10}$ and the increase in left atrial pressure ${ }^{7}$ can be expected to result in stimulation of arterial baroreceptors and intra-atrial stretch receptors, respectively, and thus reflexly augment the already increased peripheral vascular resistance. 1 Second, beta blocking drugs may directly increase the peripheral vascular resistance by blockade of the vasodilator beta- 2 adrenoceptors in striated muscle; this may also apply even to "cardioselective" drugs in the doses usually used clinically. ${ }^{7}$ Left ventricular dysfunction in patients with coronary heart disease is aggravated by any increase in aortic impedance. ${ }^{12} 13$ Thus, the vasoconstriction induced either directly or indirectly by beta blocking drugs can be expected to aggravate the primary impairment of left ventricular pumping function in these patients. As these disadvantages originate from an increase in left ventricular afterload, 
theoretically they could be countered by a concomitant reduction in aortic impedance induced by peripheral vasodilatation. The following study was undertaken to contrast the alpha beta properties of labetalol ${ }^{14}$ with propranolol to test this hypothesis that combined alpha beta blockade would be haemodynamically more advantageous in patients with stable coronary heart disease than beta blockade alone.

\section{Patients and methods}

PATIENTS (Table 1)

Twenty male patients, aged 35 to 64 years, with exercise-induced angina and electrocardiographic and angiographic evidence of severe but clinically stable coronary heart disease were studied. All were normotensive and in sinus rhythm and none had clinical or radiographic signs of left ventricular failure. There were no contraindications to beta blockade in any patient. Patients were well matched for age (propranolol 52 \pm 3 (35 to 64); labetalol 49 \pm 2 (38 to 59); the duration of angina was somewhat longer in patients on labetalol $(3.2 \pm 0.5$ years) compared with those randomised to propranolol (2.6 \pm 0.4 years). Eleven of the 20 had a history of previous myocardial infarction six to 60 months before the study: six in the propranolol (three anterior infarction) and five (four anterior) infarction) in the labetalol group. The distribution of pathological involvement of the coronary arteries was similar. Left ventricular angiography showed dyskinesia in seven of the patients randomised to propranolol (>one site involved in all) and in eight of those randomised to labetalol (>one site involved in five); none had aneurysms. Angiographic ejection fraction at rest was similar in both groups.

Short acting nitrates were the only prescribed drugs in the 72 hours before the study and no intercurrent medication was necessary in the 12 hours before any investigation. Informed consent was given by all patients and the procedure was agreed by the hospital Ethics Committee.

\section{DESIGN OF INVESTIGATION (Fig. 1)}

The study was designed as an open, between group comparison with patients randomised before the haemodynamic studies to treatment either with propranolol or labetalol. Patients were familiarised with the exercise technique beforehand and the bicycle workload which each could sustain for four minutes without distress was determined. In each patient the control study started with a four minute period of supine bicycle exercise at their predetermined symptom limiting load ( 25 to $50 \mathrm{~W}$ ); haemodynamic measurements were made during the fourth minute of the exercise period. When the circulation had restabilised, usually after 10 to 15 minutes, the resting studies were undertaken. Measurements were made during eight successive four minute periods. Hảemodynamic variables were recorded during the last two minutes of each of the first four periods after injection of $10 \mathrm{ml}$ saline into the pulmonary artery. After this either propranolol 2, 2, 4, and $8 \mathrm{mg}$ (cumulative dose 2, 4,8 , and $16 \mathrm{mg}$ ) or labetalol $10,10,20$, and $40 \mathrm{mg}$ (cumulative dose $10,20,40$, and $80 \mathrm{mg}$ ) were similarly injected and resting measurements repeated during the

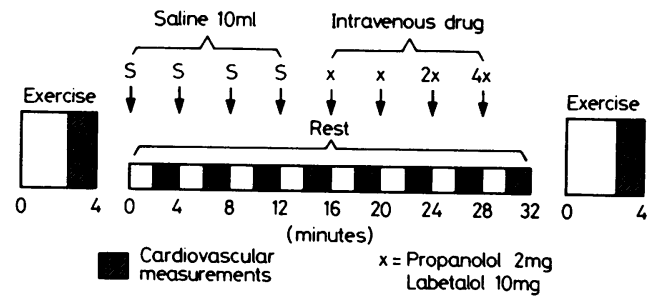

Fig. 1 Study design.

Table 1 Summary of angiographic and haemodynamic findings in patients studied

\begin{tabular}{|c|c|c|c|c|c|c|c|c|c|c|c|c|}
\hline \multirow[t]{4}{*}{ Drug } & \multicolumn{5}{|c|}{ Left ventricular angiography } & \multirow{3}{*}{\multicolumn{3}{|c|}{$\begin{array}{l}\begin{array}{l}\text { Coronary } \\
\text { angiography }\end{array} \\
\text { Vessels } \\
\text { involved }\end{array}$}} & \multicolumn{4}{|c|}{ Haemodynamic profile } \\
\hline & \multirow[t]{3}{*}{ Normal } & \multirow{2}{*}{\multicolumn{3}{|c|}{ Dyskinesia }} & \multirow{3}{*}{$\begin{array}{l}\text { Ejection } \\
\text { fraction }\end{array}$} & & & & \multicolumn{2}{|l|}{ Rest } & \multicolumn{2}{|l|}{ Exercise } \\
\hline & & & & & & & & & & & & \\
\hline & & $A n t^{\star}$ & Inf & $A p$ & & 1 & 2 & 3 & $(\mathrm{mmHg})$ & $\left(1 / \min\right.$ per $\left.m^{2}\right)$ & $(m m H g)$ & $\left(I / \min\right.$ per $\left.m^{2}\right)$ \\
\hline $\begin{array}{l}\text { Propranolol } \\
(\mathrm{n}=10)\end{array}$ & 3 & 6 & 5 & 4 & $\begin{array}{l}44 \pm 4 \\
(23-58) \S\end{array}$ & 1 & 5 & 4 & $\begin{array}{r}12 \\
\pm 1\end{array}$ & $\begin{array}{r}3.6 \\
\pm 0.2\end{array}$ & $\begin{array}{r}21 \\
\pm 2\end{array}$ & $\begin{array}{r}6.1 \\
\pm 0.4\end{array}$ \\
\hline $\begin{array}{l}\text { Labetalol } \\
(\mathrm{n}=10)\end{array}$ & 2 & 6 & 3 & 4 & $\begin{array}{l}38 \pm 6 \\
(28-65)\end{array}$ & 2 & 4 & 4 & $\begin{array}{r}12 \\
\pm \quad 2\end{array}$ & $\begin{array}{r}3.0 \\
\pm 0.2\end{array}$ & $\begin{array}{r}25 \\
\pm \quad 5\end{array}$ & $\begin{array}{r}4.4 \\
\pm 0.3\end{array}$ \\
\hline
\end{tabular}

Data presented as mean \pm SEM.

^Ant, anterior; Inf, inferior; Ap, apical.

†PAOP, pulmonary artery occluded pressure.

$\ddagger \mathrm{CO}$, cardiac output.

f(Range). 
third and fourth minutes after each injection. Patients were then immediately re-exercised for four minutes at the same bicycle workload as previously and measurements again made during the fourth minute of the exercise period. Venous blood samples for the measurement of plasma drug concentrations were taken at the time of the resting haemodynamic measurements, four minutes after each intravenous dose. The doses of propranolol and labetalol were chosen for two reasons. They encompass dose ranges often used in clinical situations, and the ratio of beta blocking activity in man between propranolol and labetalol is approximately $1: 5$ by weight. ${ }^{15}$

\section{LABORATORY TECHNIQUES, MEASUREMENTS, AND STATISTICS}

Heart rate was measured from the electrocardiogram and systemic arterial pressure through a brachial artery catheter. Pulmonary vascular pressures were measured through a balloon-tipped thermodilution catheter positioned radiographically so that inflation of the balloon resulted in replacement of the pulmonary artery pressure record by a typical pulmonary wedge tracing (pulmonary artery occluded pressure). Pressures were externally transduced with strain gauges and recorded together with heart rate on an ultraviolet recorder. Zero reference point for transduced pressures was mid-chest in the vertical plane of the sternal angle. Mean pressures were integrated electronically and heart rate and pressures were averaged over two respiratory cycles. Cardiac output was measured in triplicate by thermodilution and automatically computed (Instrumentation Laboratories 601 Computer/602 Recorder). A gas operated constant speed injector (OMP Model 3700) was used with $10 \mathrm{ml}$ dextrose saline at $0^{\circ} \mathrm{C}$ as indicator. This system is linear in vitro, with a coefficient of variance of $6 \%$ in patients at rest and $7 \%$ during steady bicycle exercise. Systemic vascular resistance was calculated by conventional means. Left ventricular ejection fraction was calculated from the planimetric measurement of the systolic and end-diastolic frames of the cineangiogram in the right anterior oblique projection.

The plasma concentration of both drugs was measured using high performance liquid chromatography with fluorimetric detection. The assay for propranolol was specific for unchanged drug, linear over the range 10 to $1000 \mathrm{ng} / \mathrm{ml}$ (coefficient of variation $7 \cdot 2 \%$ ) and with a lower limit of sensitivity of $2.5 \mathrm{ng} /$ $\mathrm{ml} .{ }^{16}$ The assay for labetalol was specific, linear over the plasma concentration range 50 to $2500 \mathrm{ng} / \mathrm{ml}$ (coefficient of variation: $5 \%$ ) and with a lower limit of sensitivity of $2 \mathrm{ng} / \mathrm{ml}$.

The probability of statistical significance of differences between control and post-drug data was tested by analysis of variance of repeated measurements. ${ }^{17}$ Tukey's multiple comparison procedure ${ }^{18}$ was used to generate the single value for two confidence levels, thus allowing the significance of differences between the incremental effects of each drug on each haemodynamic variable, both at rest and during exercise, to be ascertained.

\section{Results}

The study was accomplished without untoward incident in any patient. Eight of the 10 patients given propranolol and seven of those given labetalol volunteered the information that the severity of the exercise-induced anginal pain was less after the drug than in the control study.

\section{HOMOGENEITY OF GROUPS (Table 1)}

The randomisation achieved comparable distribution between the groups in terms of the extent of the angiographic coronary artery disease. The duration of symptoms was marginally longer in the labetalol group but their overall left ventricular performance, in terms of the relation between filling pressure and output during exercise was substantially more depressed than that of patients randomised to propranolol.

MEASUREMENTS IN CONTROL STUDIES AT REST In the control study the variability of the haemodynamic variables at rest was small in both groups and none showed any significant trend to change over the 16 minute period of measurement. For the purposes of analysis the measurements for each group from the four control periods were therefore averaged. In the resting control period the average coefficients of variation (range) for the 20 patients were: systolic blood pressure $1.7 \%(0.3$ to $2.8 \%)$, diastolic blood pressure $2 \%(1.2$ to $4.0 \%)$, heart rate $3.3 \%(0$ to $6.2 \%)$, cardiac output $3.3 \%$ (1.7 to $5.9 \%)$, and pulmonary artery occluded pressure $8 \%(3 \cdot 5$ to $12 \cdot 3 \%)$.

\section{HAEMODYNAMIC EFFECTS OF PROPRANOLOL}

(Fig. 2 and 3; Tables 2 and 3)

At rest

After the cumulative doses of propranolol there was no change in systolic, diastolic, or mean systemic arterial pressure compared with control measurements. There were, however, progressive reductions in heart rate and cardiac output and significant increases in the pulmonary artery occluded pressure and in the systemic vascular resistance.

\section{During exercise}

After the cumulative dose of $16 \mathrm{mg}$ propranolol the systolic arterial pressure was reduced $(\mathbf{p}<0.01)$ without 


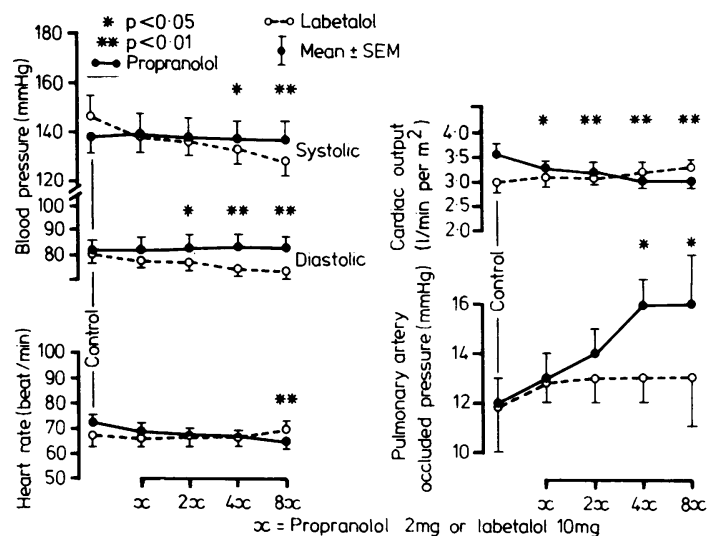

Fig. 2 Comparative haemodynamic dose response effects of propranolol and labetalol in 20 patients with coronary heart disease. Statistics related to comparison of incremental changes induced by both drugs at each of the four increasing doses.

change in the diastolic or mean pressure. Heart rate and cardiac output were both reduced $(p<0.01)$ and the systemic vascular resistance was increased $(p<0 \cdot 01)$. The pulmonary artery occluded pressure increased by an average of $7 \mathrm{mmHg}(\mathrm{p}<0.01)$.

HAEMODYNAMIC EFFECTS OF LABETALOL (Fig. 2 and 3 ; Tables 2 and 3 )

At rest

After the cumulative doses of labetalol there were statistically significant progressive reductions in

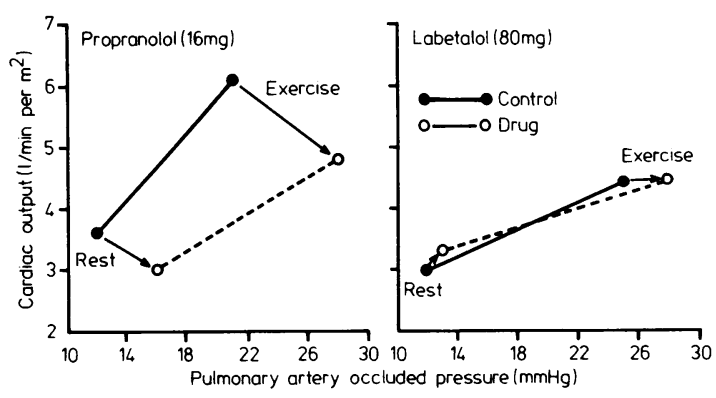

Fig. 3 Comparison of the functional relation between left ventricular filling pressure and cardiac output, at rest and during exercise, after a cumulative dose of propranolol $(16 \mathrm{mg})$ or labetalol $(80 \mathrm{mg}$ ).

systolic, diastolic, mean systemic arterial pressure, and systemic vascular resistance. there was a progressive increase in cardiac output but no significant trend of change in either heart rate or pulmonary artery occluded pressure.

\section{During exercise}

After the cumulative dose of $80 \mathrm{mg}$ labetalol there were significant reductions in systolic, diastolic, and mean systemic arterial pressure $(\mathbf{p}<0.01)$, heart rate $(\mathrm{p}<0.01)$, and systemic vascular resistance $(\mathrm{p}<0.05)$ without change in the cardiac output. The pulmonary artery occluded pressure increased by an average of $3 \mathrm{mmHg}(\mathrm{p}<0.05)$.

Table 2 Haemodynamic dose response effects of intravenous propranolol and labetalol at rest in 20 patients with severe coronary heart disease

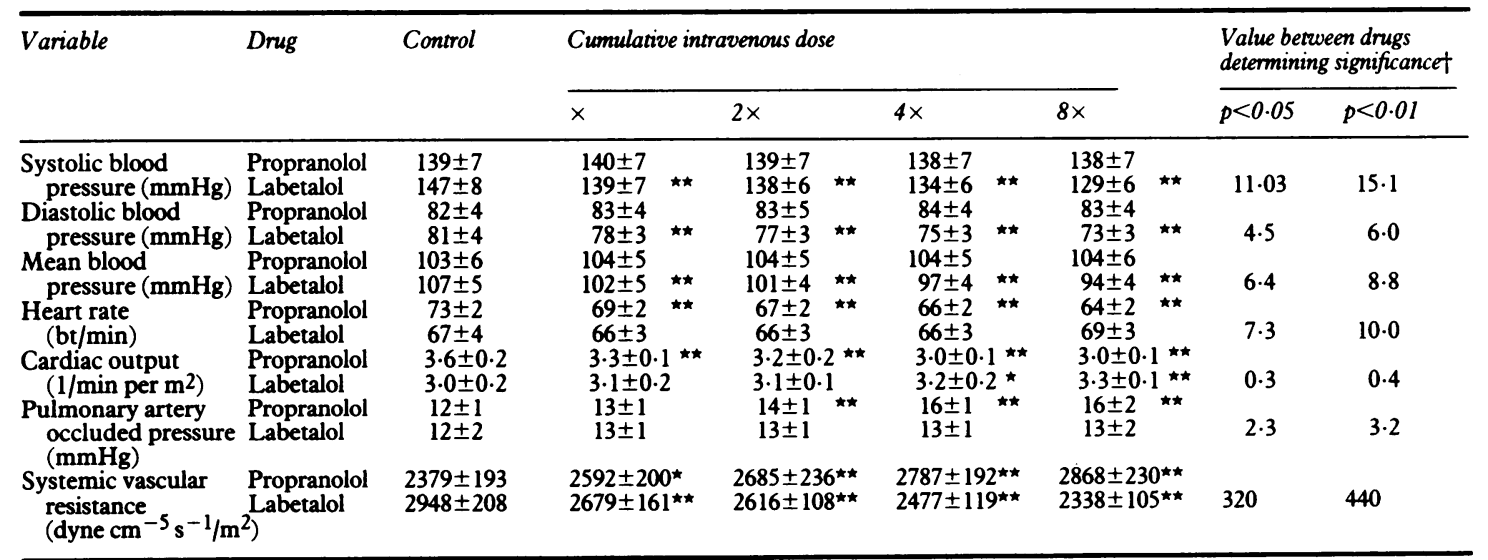

Data presented as mean \pm SEM

$\times$, propranolol $2 \mathrm{mg}$ or labetalol $10 \mathrm{mg}$.

Probability of significant difference from control ${ }_{\star \star} \mathrm{p}<0.05$

tValue for comparison of changes from control induced by the drugs at any cumulative dosage. 
Table 3 Haemodynamic effects at rest and during supine bicycle exercise after the maximum cumulative doses of propranolol (16 mg) and labetalol $(80 \mathrm{mg})$

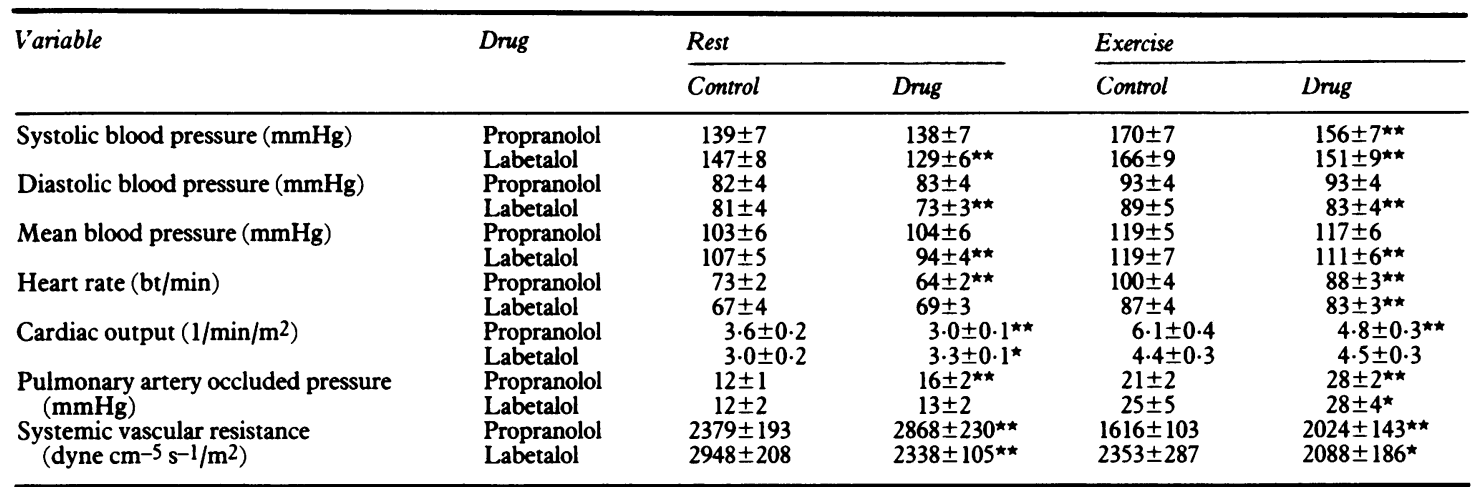

Data presented as mean \pm SEM.

Drug, propranolol $16 \mathrm{mg}$ or labetalol $80 \mathrm{mg}$.

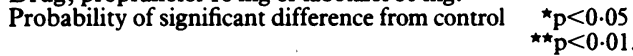

Table 4 Comparison of changes induced by equivalent beta blocking doses of propranolol and labetalol in 20 patients with coronary heart disease

\begin{tabular}{|c|c|c|c|c|c|}
\hline \multirow[t]{2}{*}{ Variable } & \multirow[t]{2}{*}{ Drug } & \multicolumn{4}{|c|}{ Cumulative intravenous dose } \\
\hline & & $x$ & $2 \times$ & $4 \times$ & $8 \times$ \\
\hline Systolic blood pressure ( $\mathrm{mmHg}$ ) & $\begin{array}{l}\text { Propranolol } \\
\text { Labetalol }\end{array}$ & $\begin{array}{l}+1 \\
-\quad 7\end{array}$ & $\begin{array}{r}0 \\
-\quad 9\end{array}$ & $\begin{array}{l}-2 \\
-13^{\star}\end{array}$ & $\begin{array}{l}-1 \\
-17^{\star \star}\end{array}$ \\
\hline Diastolic blood pressure ( $\mathrm{mmHg}$ ) & $\begin{array}{l}\text { Propranolol } \\
\text { Labetalol }\end{array}$ & $\begin{array}{l}1 \\
+\quad 1 \\
-\quad 4\end{array}$ & $\begin{array}{l}+1 \\
-\quad 5\end{array}$ & $\begin{array}{l}+2 \\
-\quad 7 \star \star\end{array}$ & $\begin{array}{l}+2 \\
-\quad 9 \star \star\end{array}$ \\
\hline Mean blood pressure ( $\mathrm{mmHg}$ ) & $\begin{array}{l}\text { Propranolol } \\
\text { Labetalol }\end{array}$ & $\begin{array}{l}+1 \\
-5\end{array}$ & $\begin{array}{l}+1 \\
-\quad 6^{\star}\end{array}$ & $\begin{array}{l}+1 \\
-10^{\star \star}\end{array}$ & $\begin{array}{l}+1 \\
-13^{\star \star}\end{array}$ \\
\hline Heart rate $(\mathrm{bt} / \mathrm{min})$ & $\begin{array}{l}\text { Propranolol } \\
\text { Labetalol }\end{array}$ & $\begin{array}{l}-4 \\
-\quad 1\end{array}$ & $\begin{array}{l}-6 \\
-\quad 1\end{array}$ & $\begin{array}{r}1 \\
-\quad 7 \\
-\quad 1\end{array}$ & $\begin{array}{l}-\quad 8 \\
+\quad 2^{\star \star}\end{array}$ \\
\hline Cardiac output (1/min per/m²) & $\begin{array}{l}\text { Propranolol } \\
\text { Labetalol }\end{array}$ & $\begin{array}{ll}- & 0.3 \\
+ & 0.1^{\star}\end{array}$ & $\begin{array}{l}-0.4 \\
+\quad 0.1^{\star \star}\end{array}$ & $\begin{array}{l}-0.5 \\
+\quad 0.2^{\star \star}\end{array}$ & $\begin{array}{ll}- & 0.6 \\
+ & 0.3^{\star}\end{array}$ \\
\hline $\begin{array}{l}\text { Pulmonary artery occluded pressure }(\mathrm{mmHg}) \\
\text { Systemic vascular resistance (dyne } \mathrm{cm}^{-5} \mathrm{~s}^{-1} / \mathrm{m}^{2} \text { ) }\end{array}$ & $\begin{array}{l}\text { Propranolol } \\
\text { Labetalol } \\
\text { Propranolol } \\
\text { Labetalol }\end{array}$ & $\begin{array}{l}+2 \\
+1 \\
+213 \\
-269 \star \star\end{array}$ & $\begin{array}{l}+3 \\
+1 \\
+306 \\
-333^{\star \star}\end{array}$ & $\begin{array}{l}+4 \\
+1^{\star} \\
+408 \\
-471^{\star \star}\end{array}$ & $\begin{array}{l}+5 \\
+1^{\star} \\
+489 \\
-610^{\star \star}\end{array}$ \\
\hline
\end{tabular}

Data presented as difference from control. $\times$, propranolol $2 \mathrm{mg}$ or labetalol $10 \mathrm{mg}$.

Statistics relate to between drug comparison at each dose level ${ }^{\star} \mathrm{p}<0.05 ;{ }^{\star \star} \mathrm{p}<0.0 \mathrm{i}$.

\section{COMPARISON OF HAEMODYNAMIC CHANGES}

INDUCED BY LOGARITHMICALLY CUMULATIVE DOSES OF PROPRANOLOL AND LABETALOL AT REST (Table 4)

Labetalol induced a linear dose related decrease in systemic arterial pressure at rest; there was no change after propranolol. The heart rate decrease after the two drugs was similar except that the highest dose of propranolol resulted in a greater decrease in heart rate than labetalol ( $p<0.01)$. Propranolol induced a significantly greater reduction in cardiac output than labetalol at all doses. There were directionally similar increases in pulmonary artery occluded pressure in both groups, but the increase was significantly greater after propranolol at the two highest doses. Propranolol increased and labetalol decreased the calculated systemic vascular resistance at all doses $(\mathrm{p}<0.01)$.

COMPARISON OF EFFECTS OF PROPRANOLOL AND LABETALOL ON LEFT VENTRICULAR PUMPING FUNCTION (Fig. 3)

The effects of propranolol and labetalol on the relation between the cardiac output and pulmonary artery occluded pressure at rest and during exercise showed distinct differences. Propranolol was followed by a significant shift to the right in the rest-to-exercise relation between left ventricular filling pressure and its pumped output $(\mathrm{p}<0.01)$; increase in filling pressure and reduction in output both contributed to this changed relation. Labetalol induced no substantial 
change in the relation between these two variables despite the initially greater overall depression of left ventricular function.

\section{PLASMA CONCENTRATIONS}

The plasma concentrations (mean $\pm S E M$ ) after the four cumulative intravenous boluses of propranolol were $77 \pm 30,92 \pm 20,191 \pm 55$, and $454 \pm 118 \mathrm{ng} / \mathrm{ml}$. The respective mean plasma concentrations of labetalol were $319 \pm 07,420 \pm 142,826 \pm 249$, and $1125 \pm 209 \mathrm{ng} /$ $\mathrm{ml}$. The plasma concentrations showed significant loglinear increases after each drug (propranolol $r=0.78$, $\mathrm{p}<0.001$; labetalol $\mathrm{r}=0.82, \mathrm{p}<0.001$ ).

\section{Discussion}

Beta blocking drugs have long been used in the symptomatic treatment of angina pectoris ${ }^{10} 19$ and in the attempt to abort post-myocardial infarction arrhythmias. ${ }^{20}$ More recently they have been advocated for secondary prevention of coronary heart disease, both orally21 22 and by the intravenous route. ${ }^{23} 24$ For the physiological and pharmacodynamic reasons already stated, however, blockade of beta adrenoceptors alone in patients with severe coronary heart disease has potential haemodynamic disadvantages. Some of these were clearly shown in our study. Propranolol was associated with a significant increase in systemic vascular resistance and left ventricular filling pressure, reflecting a substantial increase in the indices determining left ventricular afterload. ${ }^{5}$ In contrast, labetalol was not associated with any further deterioration in left ventricular pumping performance despite considerably greater impairment at the outset. As both drugs have equivalent cardiac beta blocking activity in the 5:1 ratio of the doses used in our study ${ }^{15}$ and as both are noncardioselective, the most likely cause of this striking difference in their haemodynamic activity is the vasodilatation induced by labetalol.

After propranolol, the log linear increase in plasma concentration achieved ( 77 to $454 \mathrm{ng} / \mathrm{ml}$ ) was well within the therapeutic range; antianginal activity of propranolol is present between 30 to $90 \mathrm{ng} / \mathrm{ml},{ }^{25}$ and antihypertensive activity appears at plasma concentrations in excess of $120 \mathrm{ng} / \mathrm{ml} .{ }^{26}$ Equally the log linear increase in plasma concentration of labetalol (319 to $1125 \mathrm{ng} / \mathrm{ml}$ ) exceeded that necessary to attain an equivalent degree of cardiac beta blockade (that is 150 $\mathrm{ng} / \mathrm{ml}^{27}$ ). At these plasma concentration ranges the immediate haemodynamic effects of the two drugs were in sharp contrast both at rest and during dynamic exercise. At rest propranolol resulted in a dose related depression of cardiac pumping activity; the increase in systemic vascular resistance was presumably both reflex in origin (from the increase in left atrial pressure ${ }^{28}$ ) and also the result of direct blockade of vasodilator beta-2 adrenoceptors in the peripheral arteriolar resistance vessels. In contrast, labetalol resulted in a dose related increase in the pumped output of the left ventricle at the same filling pressure and heart rate, presumably because of the reduction in left ventricular afterload consequent upon its direct vasodilator activity. During exercise the separation of the haemodynamic effects of the two drugs was even greater, despite the greater initial impairment of left ventricular performance in the labetalol group. In the latter group the relation between the filling pressure of the left ventricle and its output was largely unchanged by combined alpha and beta blockade whereas this haemodynamic relation was significantly depressed after propranolol. Again, presumably as a reflection of further depression of left ventricular function, the systemic vascular resistance during exercise was increased after propranolol but unchanged after labetalol. Thus, the contrasting pharmacodynamic effects of the two drugs in these patients with coronary heart disease were largely explicable by the possession of vasodilator alpha adrenoceptor blocking activity by labetalol.

These results with propranolol are in accord with previous single dose 2930 and multiple dose response studies $^{31}$ in patients with coronary heart disease. The circulatory effects of labetalol in normal volunteers, ${ }^{15}$ and in patients with essential hypertension, ${ }^{32}$ were similar to those we recorded in our patients. The only other haemodynamic evaluation of labetalol in normotensive patients with angina pectoris was a single dose study carried out at rest. ${ }^{33}$ Ten minutes after an average intravenous bolus of $1.5 \mathrm{mg} / \mathrm{kg}$ systemic blood pressure and vascular resistance were reduced to a similar order to that after the maximum cumulative dose in the present study, cardiac output was unchanged and there was a small insignificant fall in pulmonary wedge pressure. These ,results are compatible with ours and highlight the important influence of dose response studies and physiological exercise in analysing the haemodynamic effects of a drug.

How far these results can be extrapolated to the medical treatment of patients with angina cannot be decided from these studies. Labetalol, however, has been shown to be symptomatically effective, both in normotensive (unpublished observations) and hypertensive patients with angina pectoris. ${ }^{34} 35$ Our results also suggest that the drug may be particularly useful in the treatment of angina patients with severe left ventricular dysfunction or in those with an inadequate response to beta blocking drugs alone.

It is important, however, to emphasise that these observations, however haemodynamically instructive, were based on the results of intravenous studies, and 
can be extended to the wider therapeutic field only with caution. Definitive studies of the clinical efficacy of combined alpha and beta blockade during long term treatment of patients with angina pectoris and those with asymptomatic coronary heart disease undergoing secondary preventive treatment are necessary before the true therapeutic value of this new pharmacological approach can be decided. Our results, however, furnish an optimistic basis for the institution of such studies in patients with stable coronary heart disease.

We thank Miss Anne Storey for statistical advice. This study was supported by grants from Glaxo Research (UK) Ltd and the Yorkshire Regional Hospital Board.

\section{References}

1 Parker JO, Di Giorgi S, West RO. A hemodynamic study of acute coronary insufficiency precipitated by exercise. Am f Cardiol 1966; 17: 470-83.

2 Dwyer EM Jr. Left ventricular pressure-volume alterations and regional disorders of contraction during myocardial ischemia induced by atrial pacing. Circulation 1970; 42: 1111-22.

3 Sharma B, Taylor SH. Reversible left ventricular failure in angina pectoris. Lancet 1970; ii: 902-7.

4 Sonnenblick EH, Ross J Jr, Covell JW, Kaiser GA, Braunwald E. Velocity of contraction as a determinant of myocardial oxygen consumption. Am f Physiol 1965; 209: 919-27.

5 Braunwald E. Thirteenth Bowditch Lecture. The determinants of myocardial oxygen consumption. Physiologist 1969; 12: 65-93.

6 Reale A, Nigri A, Gioffrè PA, Motolese M. Acute influence of different beta-blocking agents upon left heart hemodynamics at rest and during exercise in patients with coronary heart disease. Eur $\mathcal{F}$ Cardiol 1979; 9: 101-9.

7 Taylor SH, Silke B, Lee PS. Intravenous beta-blockade in coronary heart disease: is cardioselectivity or intrinsic sympathomimetic activity hemodynamically useful? $N$ Engl f Med 1982; 306: 631-5.

8 Coltart DJ, Alderman EL, Robinson SC, Harrison DC. Effect of propranolol on left ventricular function, segmental wall motion and diastolic pressure-volume relation in man. Br Heart $\mathcal{A}$ 1975; 37: 357-64.

9 Dehmer GJ, Falkoff M, Lewis SE, Hillis LD, Parkey RW, Willerson JT. Effect of oral propranolol on rest and exercise left ventricular ejection fraction, volumes and segmental wall motion in patients with angina pectoris. Assessment with equilibrium gated blood pool imaging. Br Heart f 1981; 45: 656-66.

10 Thadani U, Davidson C, Singleton W, Taylor SH. Comparison of the immediate effects of five betaadrenoceptor blocking drugs with different ancillary properties in angina pectoris. $N$ Engl F Med 1979; 300: $750-5$.

11 White C de B, Udwadia BP. Beta adrenoceptors in the human dorsal hand vein, and the effects of propranolol and practolol on venous sensitivity to noradrenaline. $\mathrm{Br} \mathcal{O}$ Clin Pharmacol 1975; 2: 99-105.

12 Helfant RH, De Villa MA, Meister SG. Effect of $\overrightarrow{\bar{B}}$ sustained isometric hand-grip exercise on left ventricular performance. Circulation 1971; 44: 982-93.

13 Quinones MA, Gaasch WH, Waisser E, Thiel HG, Alexander JK. An analysis of the left ventricular response to isometric exercise. Am Heart f 1974; 88: 29-36.

14 Richards DA, Prichard BNC. Clinical pharmacology of labetalol. Br J Clin Pharmacol 1979; 8: 89s-93s.

15 Richards DA, Prichard BNC, Dobbs RJ. Adrenoceptor blockade of the circulatory responses to intravenous isoproterenol. Clin Pharmacol Ther 1978; 24: 264-73.

16 Holt DW, Bhamra RK, Flanigan RJ, Tynan MJ. A rapid high performance liquid chromatographic method for the measurement of propranolol in small samples of blood, $\infty$ plasma or serum at the concentrations attained during + therapy (abstract). Unpublished Proceedings of the lst $\mathcal{O}^{\circ}$ International Congress of Paediatric Laboratory Medicine, Jerusalem, 1980.

17 Biomedical Computer Programme-“P” Series. Dixon WJ, Brown MB, eds. Berkely: University of California Press, 1979: 540-80.

18 Winer BJ. Statistical principles in experimental design. 2nd ed. New York: McGraw-Hill, 1971: 197-200.

19 Prichard BNC, Aellig WH, Richardson GA. The action of intravenous oxprenolol, practolol, propranolol and sotalol on acute exercise tolerance in angina pectoris; the effect on heart rate and the electrocardiogram. Postgrad Med $\mathcal{F}$ 1970; 46, suppl: 77-85.

20 Singh BN, Jewitt DE. Beta-adrenergic receptor blocking drugs in cardiac arrhythmias. Drugs 1974; 7: 426-61.

21 Norwegian Multicenter Study Group. Timolol-induced $\stackrel{\mathbb{D}}{\circ}$ reduction in mortality and reinfarction in patients $\overrightarrow{\vec{D}}$ surviving acute myocardial infarction. $N$ Engl f Med 1981; 304: 801-7.

22 Beta-blocker Heart Attack Trial Research Group. A randomized trial of propranolol in patients with acute myocardial infarction. I: Mortality results. $\mathcal{F A M A} 1982$; 247: 1707-14.

23 Yusuf S, Ramsdale D, Peto R, et al. Early intravenous atenolol treatment in suspected acute myocardial infarction. Lancet 1980; ii: 273-6.

$24 \mathrm{Hjalmarson}$ A, Elmfeldt D, Herlitz J, et al. Effect on mortality of metoprolol in acute myocardial infarction. Lancet 1981; ii: 823-7.

25 Pine M, Favrot L, Smith S, McDonald K, Chidsey CA. D Correlation of plasma propranolol concentration with therapeutic response in patients with angina pectoris. Circulation 1975; 52: 886-93.

26 Chidsey CA, Morselli P, Bianchetti G, Morganti A, N Leonetti G, Zanchetti A. Studies of the absorption and $\mathcal{N}$ removal of propranolol in hypertensive patients during therapy. Circulation 1975; 52: 313-8.

27 Richards DA, Maconochie JG, Bland RE, Hopkins R, Woodings EP, Martin LE. Relationship between plasma concentrations and pharmacological effects of labetalol. Eur F Clin Pharmacol 1977; 11: 85-90.

28 Furnival CM, Linden RJ, Snow HM. Inotropic changes

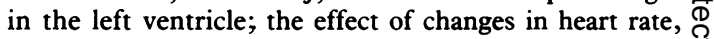
aortic pressure and end-diastolic pressure. $\mathcal{F}$ Physiol (Lond) 1970; 211: 359-87. 
29 Grandjean T, Rivier JL. Cardio-circulatory effects of beta-adrenergic blockade in organic heart disease. $\mathrm{Br}$ Heart f 1968; 30: 50-9.

30 Parker JO, West RO, Di Giorgi S. Hemodynamic effects of propranolol in coronary heart disease. Am $\mathcal{F}$ Cardiol 1968; 21: 11-19.

31 Svendsen TL, Hartling OJ, Trap-Jensen J, McNair A, Bliddal J. Adrenergic beta-receptor blockade: hemodynamic importance of intrinsic sympathomimetic activity at rest. Clin Pharmacol Ther 1981; 29: 711-8.

32 Koch G. Cardiovascular dynamics after acute and longterm alpha- and beta-adrenoceptor blockade at rest, supine and standing, and during exercise. $\mathrm{Br} \mathcal{F} \mathrm{Clin}$ Pharmacol 1979; 8: 101s-5s.

33 Gagnon RM, Morissette M, Presant S, Savard D, Lemire J. Hemodynamic and coronary effects of intravenous labetalol in coronary artery disease. Am $\mathcal{F}$ Cardiol 1982; 49: 1267-9.

34 Besterman EMM, Spencer $M$. Open evaluation of labetalol in the treatment of angina pectoris occurring in hypertensive patients. Brf Clin Pharmacol 1979; 8, Suppl 2: 205s-9s.

35 Frishman WH, Strom JA, Kirschner M, et al. Labetalol therapy in patients with systemic hypertension and angina pectoris: effects of combined alpha- and betaadrenoceptor blockade. Am F Cardiol 1981; 48: 917-28.

Requests for reprints to Dr S H Taylor, Department of Medical Cardiology, The General Infirmary, Great George Street, Leeds LS1 3EX. 